\title{
Wirus Epsteina-Barr w wybranych chorobach nowotworowych
}

\begin{abstract}
STRESZCZENIE
Tnfekcje wirusowe przyczyniają się do wielu nowotworów na całym świecie i stanowią listotny odsetek śmiertelności. Do onkogennych wirusów zaliczany jest wirus Epsteina-Barr, który jest główną przyczyną mononukleozy zakaźnej i wykazuje tropizm względem limfocytów B. Dzięki obecności genów odpowiedzialnych za latencję może przyczyniać się do wielu stanów patologicznych. Przykładami tego są nowotwory złośliwe o wysokiej śmiertelności zlokalizowane $\mathrm{w}$ żołądku, a także głowie oraz szyi. Ponadto wirus ten jest poważnym zagrożeniem dla osób z obniżoną odpornościa, co stanowi w obecnych czasach istotny problem ze względu na rosnącą liczbę chorych poddanych terapii immunosupresyjnej. Na szczególną uwagę w tym przypadku zasługują zaburzenia limfoproliferacyjnie po przeszczepie będące złośliwym nowotworem powiązanym z infekcją EBV. W niniejszym przeglądzie skupiono się na roli wirusa Epsteina-Barr w wybranych nowotworach.
\end{abstract}

\section{WPROWADZENIE}

Choroby nowotworowe na całym świecie stanowią drugą po chorobach układu krążenia przyczynę zgonu. Dotychczas odkryto ponad 277 typów raka. Nowotwór powstaje w wyniku mutacji genów w konsekwencji czego dochodzi do nieprawidłowej proliferacji komórek. Choroba ta zaburza relacje komórkowe i powoduje dysfunkcję ważnych genów. Związki chemiczne, wirusy, bakterie i promienie radiacyjne powodują zmiany w komórkach będące przyczyną rozwoju nowotworów. Prawidłowe wersje genów, zwane protoonkogenami odpowiadają za proliferację zdrowych komórek. W wyniku modyfikacji genetycznej ulegają one uszkodzeniu, stając się onkogenami. Zmiana ta może powodować nieprawidłową stymulację cyklu komórkowego i prowadzić do transformacji nowotworowej [1]. Dotychczas poznano osiem wirusów stanowiących ważną przyczynę raka szczególnie w słabiej rozwiniętych krajach. Są one istotnym zagrożeniem dla osób z osłabionym układem odpornościowym i nie tylko. Ich poznanie doprowadziło do odkrycia wielu onkogenów i genów supresorowych nowotworu. Choroby nowotworowe wywołane przez te cząstki zakaźne można uznać za pewien rodzaj „wypadku biologicznego”, ponieważ prowadzą do śmierci zarówno gospodarza jak i wirusa. Należy podkreślić, że wywoływanie raka nie jest związane z podstawową częścią cyklu życiowego wirusów onkogennych $[2,3]$. Aby wirus został uznany za czynnik etiologiczny choroby nowotworowej, muszą zostać spełnione następujące warunki: musi istnieć związek przyczynowy między guzem a pojawieniem się wirusa, należy ustalić obecność antygenu lub genomu wirusa w komórkach nowotworowych, wirus wyizolowany z tkanki nowotworowej po pasażu powinien transformować komórki in vitro $[4,5]$.

\section{CHARAKTERYSTYKA WIRUSA EPSTEINA-BARR}

Obok zmian genetycznych i epigenetycznych do przyczyn nowotworów zalicza się wirusy onkogenne. Jednym z nich jest wirus Epsteina-Barr (EBV) odkryty w 1964 roku w hodowli limfoblastów pochodzących z chłoniaka Burkitta. Ten herpeswirus infekujący ludzkie limfocyty posiada materiał genetyczny w postaci dwuniciowego DNA. Informacja genetyczna wirusa okryta jest przez ikosaedralny kapsyd i otoczona tegumentem. Najbardziej zewnętrzną część stanowi osłonka tworzona przez podwójną warstwę lipidową z glikoproteinami. Budowę wirusa Epsteina-Barr przedstawia rycina 1. EBV jest główną przyczyną mononukleozy zakaźnej, której objawy obejmują gorączkę, powiększenie węzłów chłonnych oraz zapalenie gardła. Jednak tylko niewielka część przypadków tej choroby ma ostre powikłania takie jak zapalenie wątroby, pęknięcie śledziony czy ciężkie powiększenie migdałków z niedrożnością dróg oddechowych. Szacuje się, że ponad 90\% ludzkiej populacji przeszło zakażenie tym patogenem, co zalicza go do najczęściej występujących wirusów infekujących ludzi. W zdecydowanej większości przypadków zakażenia te są bezobjawowe. EBV jest przeno-

\section{mgr Marcin Koleśnik ${ }^{1 凶}$}

\section{dr Anna Dworzańska²,}

\section{prof dr hab Małgorzata Polz- -Dacewicz ${ }^{1}$}

${ }^{1}$ Zakład Wirusologii z Laboratorium SARS, Uniwersytet Medyczny w Lublinie ${ }^{2}$ Mazowiecki Szpital Specjalistyczny w Radomiu

https://doi.org/10.18388/pb.2020_364

๑autor korespondujący: marcinkolesnik@ umlub.pl

Słowa kluczowe: wirus Epsteina-Barr, choroby nowotworowe, infekcja wirusowa

Wykaz skrótów: AIDS (ang. acquired immunodeficiency syndrome) - zespół nabytego niedoboru odporności, EBER (ang. Epstein-Barr virus-encoded small RNA) - małe RNA kodowane przez wirusa Epsteina-Barra, EBNA (ang. Epstein-Barr nuclear antygen) - antygen jądrowy Epsteina-Barr, EBV (ang. Epstein-Barr virus) - wirus Epsteina-Barr, EBVaGC (ang Epstein-Barr virus-associated gastric carcinoma) rak żołądka związany z wirusem Epsteina-Barr, LMP (ang. latent membrane protein) - utajone białko błonowe, NPC (ang. nasopharyngeal carcinoma) - rak jamy nosowo-gardłowej, PTLD (ang. Post-Transplant Lymphoproliferative Disease) - choroba limfoproliferacyjna po przeszczepie, WHO (ang. World Health Organization) - Światowa Organizacja Zdrowia 


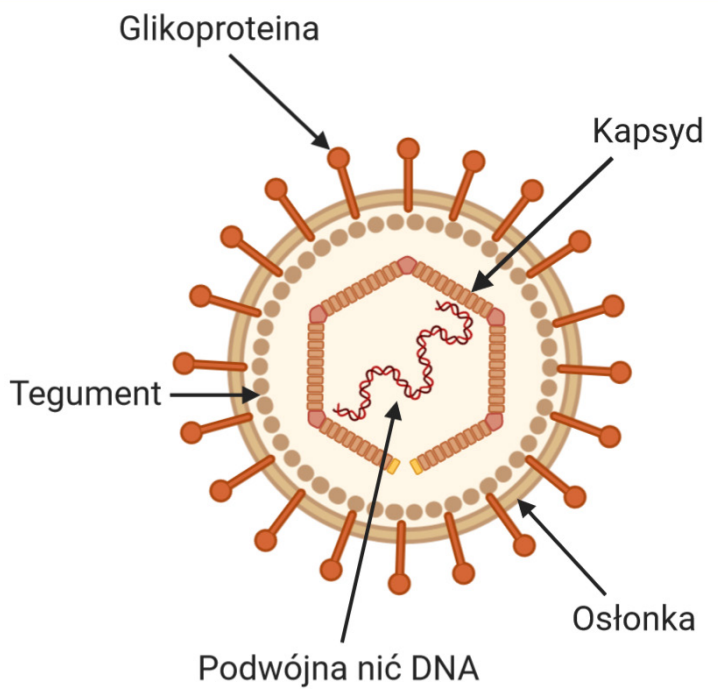

Rycina 1. Ogólny schemat budowy wirusa Epsteina-Barr.

szony wraz ze śliną i uznaje się, że jego replikacja rozpoczyna się w momencie przechodzenia zakażonych limfocytów przez nabłonek jamy ustnej i gardła. Następnie zakażane są komórki błon śluzowych w celu dalszego namnażania i wydalania do śliny. Wirus ten może być również przenoszony przez przeszczepy narządów i transfuzje krwi. EBV unika rozpoznania przez układ immunologiczny na przykład poprzez ograniczenie ekspresji swoich genów do 9 białek z około 100 możliwych do syntezy. Dzięki temu może przejść w stan utajonej infekcji. EBV stanowi istotne zagrożenie dla osób starszych z obniżoną odpornością po przeszczepach i chorych na AIDS (zespół nabytego niedoboru odporności). Może w tych przypadkach dojść do reaktywacji zakażenia i w konsekwencji wywołania groźnych chorób. Wirus ten zalicza się do przyczyn zaburzeń limfoproliferacyjnych, zespołu chronicznego zmęczenia, chorób tarczycy, stwardnienia rozsianego i reumatoidalnego zapalenia stawów. Znane są dwa podtypy EBV: 1 i 2. Różnią się one regionem kodującym antygen jądrowy (EBNA). Pierwszy z wymienionych dominuje w Europie i jest na ogół częściej spotykany. EBV-2 natomiast występuje w Afryce Centralnej i Nowej Gwinei.

\section{WIRUS EPSTEINA-BARR A CHOROBY NOWOTWOROWE}

EBV jest pierwszym ludzkim wirusem, któremu przypisano potencjał onkogenny. Został zaliczony do grupy 1 jako rakotwórczy przez Międzynarodową Agencję Badań nad Rakiem Światowej Organizacji Zdrowia [5-11]. Wykrycie DNA EBV w komórkach raka jamy nosowo-gardłowej oraz w chłoniaku Burkitta potwierdziło związek tego wirusa z chorobami nowotworowymi [12]. Wykazuje on powiąza- nie z około 1,8\% wszystkich przypadków śmiertelnych na całym świecie spowodowanych nowotworami. Biorąc pod uwagę fakt, iż wskaźnik zgonów wywołanych nowotworami nadal wrasta o około $2 \%$ rocznie, zasadne jest skoncentrowanie się na tym problemie. Infekcje EBV są powiązane $\mathrm{z}$ wieloma różnymi nowotworami złośliwymi pochodzenia limfoidalnego i nabłonkowego. Wykazano między innymi zdolność tego wirusa do transformacji ludzkich limfocytów B do linii limfoblastoidalnych [13,14]. EBV jest również powiązany z kilkoma nowotworami złośliwymi, takimi jak chłoniak Hodgkina i rak żołądka. Występuje on w komórkach nowotworowych głównie $\mathrm{w}$ stanie latencji, jednak niewielka liczba komórek zakażonych litycznie promuje nowotworzenie poprzez uwalnianie czynników wzrostu i onkogennych cytokin [15].

Wirusowe produkty genowe ulegają ekspresji w prawie wszystkich nowotworach powiązanych z EBV. Powstałe białka przyczyniają się do onkogenezy poprzez blokowanie apoptozy, zwiększanie niestabilności genomu czy indukcje niekontrolowanej proliferacji i migracji komórek [16]. Na uwagę zasługują białka latentne kodowane przez EBV, które pośredniczą $\mathrm{w}$ transformacji nowotworowej. Należą do nich utajone białka błonowe (LMP1, LMP2A, LMP2B), antygeny jądrowe (EBNA-1, $-2,-3 \mathrm{~A},-3 \mathrm{~B},-3 \mathrm{C},-\mathrm{LP}) \mathrm{i}$ transkrypty RNA (EBER-1, -2). Przyczyniają się one do progresji raka odgrywając kluczową rolę zarówno w przypadku guzów pierwotnych jak i podczas przerzutów. Geny ulegające ekspresji w różych typach latencji i choroby z nimi związane przedstawia Tabela 1. Różne mechanizmy genetyczne wykorzystywane przez EBV do wywoływania guzów w zainfekowanych komórkach są złożonymi procesami. Obejmują one ekspresję niektórych białek wirusowych i wyłączanie innych [5,17-20].

Niektóre nowotwory powiązane z EBV, takie jak chłoniak Burkitta czy rak jamy nosowo-gardłowej są endemiczne i wykazują tendencyjne rozmieszczenie w różnych obszarach na świecie. Co ciekawe, endemiczne chłoniaki Burkitta są prawie $100 \%$ EBV-pozytywne, a wiele nieendemicznych jest EBV-negatywnych. Istotna część nowotworów złośliwych powiązanych z infekcją EBV występuje w Azji. Interesujący jest fakt, że poszczególne rodzaje nowotworów występują $\mathrm{w}$ różnych obszarach na tym kontynencie. Dobrym przykładem może być tutaj chłoniak T/NK powiązany z infekcją EBV wykrywany zwykle w Japonii i Korei, gdzie częstość występowania raka nosogardzieli jest niewielka. Możliwymi wyjaśnieniami powiązania EBV z różnymi nowotworami złośliwymi na różnych obszarach Azji są różnice w podłożu genetycznym gospodarza oraz różnorodność szczepów EBV. Identyfikacja wysokiego ryzyka infekcji EBV sprawia ogromną trudność ze względu na to, iż wiele genów wirusowych współpracuje w nabywaniu potencjału onkogennego [21].

Tabela 1. Ekspresja genów wirusowych EBV w różnych typach latencji i przykłady powiązanych z nimi jednostek chorobowych.

\begin{tabular}{lll} 
Typ latencji & Geny ulegające ekspresji & Przykład jednostki chorobowej \\
0 & EBERs & Rozrost limfocytów B \\
I & EBERs, EBNA1, BARTs & Chłoniak Burkitta, choroba Hodgkin'a \\
II & EBERs, EBNA1, LMPs, BARTs & Rak nosogardła \\
III & EBERs, EBNA1, EBNA2, EBNA3A, EBNA3B, & Zaburzenia limfoproliferacyjne po przeszczepie (PTLD) \\
\hline
\end{tabular}




\section{ROLA WIRUSA EPSTEINA-BARR W RAKU ŻOŁACDKA}

Rak żołądka jest piątym najczęściej występującym nowotworem złośliwym na świecie i pomimo znacznego zmniejszenia częstości występowania pozostaje trzecią najczęstszą przyczyną zgonów z powodu raka. W Cancer Genome Atlas Research Network zaproponowano podział raka żołądka na 4 podtypy molekularne: rak żołądka związany z zakażeniem EBV, guzy niestabilne chromosomowo, guzy niestabilne mikrosatelitarne i stabilne genomowo guzy. Szacuje się, że około 10\% nowotworów żołądka jest spowodowana przez wirusa EBV. Jego obecność u pacjentów z rakiem żołądka została po raz pierwszy opisana w nowotworze chłoniakopodobnym tego narządu [10,22,23]. Infekcja EBV może prowadzić zarówno do przewlekłego zapalenia żołądka, jak i kancerogenezy [4].

Nowotwór żołądka nie wykazuje tendencyjnego rozmieszczenia geograficznego [21]. Najwyższą zachorowalność na tę chorobę odnotowano w Niemczech i USA, a najniższą w Chinach [19]. Rak żołądka związany z zakażeniem EBV (EBVaGC) jest wynikiem monoklonalnej proliferacji komórek nowotworowych latentnie zainfekowanych wirusem Epstein-Barr [24]. Częstotliwość tego nowotworu powiązanego z EBV na świecie waha się od 2-20\%, średnio około $10 \%$. Różnice te są spowodowane czynnikami geograficznymi i środowiskowymi. Szacuje się, że u około 75000-90000 ludzi rocznie rozwija się rak żołądka powiązany z EBV [25]. Należy również dodać, iż ryzyko nowotworu żołądka wzrasta wraz z koinfekcją Helicobacter pylori i EBV [26].

EBVaGC jest najbardziej powszechnym nowotworem złośliwym wywoływanym przez EBV. Jego lokalizacja dotyczy zwykle środkowej lub górnej części żołądka i objawia się jako powierzchownie zagłębione lub owrzodzone zmiany. Stwierdzono, że EBV-dodatni rak żołądka ma odmienny profil ekspresji białek i cechy kliniczno-patologiczne w porównaniu z EBV-ujemnym. Cechy EBVaGC obejmują: częste zmiany $\mathrm{w}$ genie PIK3CA, hipermetylację DNA, amplifikację JAK2 oraz nadekspresję PD-L1 i PD-L2 [23,19]. EBV koduje zarówno geny wirusowe i miRNA za pomocą własnej sekwencji DNA. Geny tego wirusa są niezbędne do utrzymania stanu latencji i przyczyniają się przez to do właściwości onkogennych. EBVaGC jest powiązany z latencją typu I. Specyficznej ekspresji $\mathrm{w}$ tych nowotworach ulegaja kodowane przez EBV: małe RNA (EBER), antygen jądrowy (EBNA 1) oraz nietranskrybowane RNA. Małe RNA kodowane przez EBV były widoczne w każdej komórce nowotworu żołądka. MiRNA kodowane przez EBV przyczyniają się do inicjacji i progresji nowotworów związanych z EBV. Dobrym przykładem w przypadku EBV powiązanego z nowotworami mogą być tutaj członkowie rodziny BART miRNA przyspieszający kancerogenezę poprzez celowanie w geny wirusa lub komórki gospodarza [27]. Pomimo wielu postępów mechanizmy nowotworu żołądka powiązanego z EBV ciągle nie zostały w pełni wyjaśnione [28].

\section{ROLA WIRUSA EPSTEINA-BARR W NOWOTWORACH GŁOWY I SZYI}

Nowotwory obejmujące głowę i szyję dotyczą jamy ustnej, nosa, krtani, gardła i ślinianek. Są dziesiątym najczęściej spotykanym nowotworem na świecie [29]. Co roku odnotowuje się ponad 600 tysięcy nowych przypadków i ponad 350 tysięcy zgonów [30]. Większość spośród nich wywodzi się z nabłonka błony śluzowej jamy ustnej, gardła i krtani. Biorąc pod uwagę histologię, większość nowotworów głowy i szyi stanowi rak płaskonabłonkowy, który występuje w około 90\% wszystkich przypadków. Do innych typów należą chłoniaki, mięsaki i blastomy [29]. Istotnym problemem związanym z tymi nowotworami jest ich późna detekcja. Ponadto nowotwory głowy i szyi cechują się wysoką śmiertelnością. Jako główne przyczyny podaje się kancerogeny zawarte w dymie tytoniowym, alkohol, nieprawidłową higienę jamy ustnej, niewłaściwą dietę oraz zakażenie wirusem brodawczaka ludzkiego (HPV) i Epsteina-Barr (EBV). Wirusy te są powiązane z rozwojem i progresją raka głowy i szyi. W przypadku niezróżnicowanego raka jamy nosowo-gardłowej wszystkie przypadki są związane z EBV [29,30].

EBV występuje w formie latentnej w większości nowotworów powiązanych z nabłonkiem w przeciwieństwie do prawidłowego nabłonka, gdzie dochodzi zwykle do infekcji litycznej. Jest to istotna informacja pozwalająca stwierdzić, że ustalenie utajonej infekcji EBV może stanowić krytyczny etap w patogenezie nowotworów nabłonka [31]. Kluczowymi białkami odpowiadającymi za onkogenność EBV są LMP1, LMP2 i EBNA. Biorą one udział w ograniczaniu apoptozy, promują angiogenezę i ulegają częstej ekspresji w ludzkim nowotworze jamy nosowo-gardłowej i ustnej. Są one zaangażowane w progresję raka, jego inwazyjność i przerzuty, a także unikanie odporności immunologicznej [29,32]. W przypadku raka nosogardzieli związanego z EBV obserwuje się latencję typu II, w której to ekspresji ulegają EBER1/2, EBNA, LMP1, LMP2, BARF1 i pewna liczba miRNA w regionach BART. EBER i EBNA1 są wykrywane we wszystkich komórkach nowotworowych. Wśród produktów tych latentnych genów, EBNA1 jest niezbędne do zarządzania replikacją i segregacją mitotyczną episomów EBV, utrzymując genomy EBV w komórkach zainfekowanych latentnie [33]. Dowiedziono również, że LMP1 i LMP2 mają silny wpływ na ekspresję genów komórkowych i proliferację, prowadząc do wysoce inwazyjnego i złośliwego wzrostu raka nosogardzieli [19]. Zaobserwowano udział obydwu typów wirusa: EBV1 i EBV2 w raku jamy nosowo-gardłowej. U osób z południowych Chin, Azji Południowo-Wschodniej, Afryki i USA większość przypadków tego nowotworu wiąże się z infekcją EBV1. EBV wykazuje latencję typu II w niezróżnicowanych NPC. Co ciekawe, komórki raka jamy nosowo-gardłowej są rozpoznawane przez cytotoksyczne limfocyty T, ale nie ulegają degradacji. Odnotowano również, że IL-10 kodowana przez EBV i będąca wirusowym homologiem ludzkiej IL-10 dodatnio wpływa na NPC. Ponadto sugeruje się, że Bcl-2 może odgrywać rolę w progresji tej choroby umożliwiając komórce uniknięcie apoptozy [34].

\section{ROLA WIRUSA EPSTEINA-BARR W ZABURZENIACH LIMFOPROLIFERACYJNYCH PO PRZESZCZEPIE}

Do nowotworów złośliwych pochodzących z limfocytów B zalicza się zaburzenia limfoproliferacyjne po przeszczepie (PTLD). Są one połączeniem zmian postępujących od atypowej proliferacji poliklonalnych limfocytów B u osób z ob- 
niżoną odpornością do bardziej agresywnych chłoniaków, które mogą się utrzymać jako nowotwory złośliwe nawet po przywróceniu odporności [19]. U pacjenta z prawidłową odpornością proliferacja komórek $\mathrm{B}$ jest kontrolowana przez cytotoksyczne limfocyty $\mathrm{T}$, podczas gdy u pacjenta z obniżoną odpornością niekontrolowana aktywacja komórek B i ciągła proliferacja prowadzi do PTLD. Dotychczas zdefiniowano różne zaburzenia limfoproliferacyjne po przeszczepie, takie jak rozrost plazmocytowy, polimorficzne zaburzenia limfoproliferacyjne, złośliwe chłoniaki nieziarnicze czy szpiczaki mnogie [34]. W warunkach klinicznych są one obserwowane $u$ pacjentów po przeszczepach tkanek i u osób z wrodzonym niedoborem odporności, takich jak osoby cierpiące na zespół Wiscotta-Aldricha czy zespół limfoproliferacyjny sprzężony $\mathrm{z}$ chromosomem $\mathrm{X}$ [19]. Około 60-80\% przypadków PTLD została powiązana z infekcją EBV. Częstość występowania PTLD jest bardzo zróżnicowana $\mathrm{w}$ zależności od przeszczepianego narządu, stanu wirusa EBV u dawcy i biorcy, a także od rodzaju terapii immunosupresyjnej. Ponad 90\% PTLD związanego z tym wirusem ma wczesny początek [35]. Diagnoza PTLD opiera się na klasyfikacji Światowej Organizacji Zdrowia (WHO) i obejmuje cztery kategorie: wczesne zmiany (niedestrukcyjne PTLD), polimorficzne, monomorficzne i chłoniak Hodgkina. W przypadku przeszczepów zarówno narządów litych, jak i hematologicznych komórek macierzystych, ryzyko PTLD zależy od rodzaju wykonanego przeszczepu. U dorosłych największe ryzyko występuje po przeszczepach wielonarządowych i jelitowych (>20\%), płuc (3-10\%), serca (2-8\%) i wątroby (1-5,5\%) [36]. Większość z tych chorób charakteryzuje się wzorcem ekspresji genów latencji typu III, ale obserwowano również latencje typu I i II. LMP1 kodowane przez EBV można określić jako główny protoonkogen ulegający ekspresji w większości PTLD $\mathrm{z}$ dodatnim EBV. Białko to odpowiada za aktywację kilku szlaków sygnałowych, które przyczyniają się do ekspresji białek antyapoptotycznych, takich jak Bcl-2 czy A20 oraz niektórych cytokin. Prawie wszystkie rodzaje tych zaburzeń są powiązane $\mathrm{z}$ tym wirusem a pojawianie się błędów na poziomie molekularnym silnie wpływa na rozwój złośliwości tego nowotworu [34-36].

\section{PODSUMOWANIE}

Nowotwory powiązane z infekcją wirusem Epsteina-Barr stanowią istotny problem dla zdrowia publicznego. Wśród nich można wyróżnić te stanowiące ogromne zagrożenie, jak rak żołądka, głowy i szyi oraz zaburzenia limfoproliferacyjne po przeszczepie. Onkogenność EBV jest podyktowana w dużym stopniu ekspresją określonych genów latentnych wirusa pozwalających na uniknięcie zniszczenia przez układ immunologiczny gospodarza. Wpływają one również w dużym stopniu na inwazyjność i rozprzestrzenianie się poszczególnych nowotworów. Pomimo ogromnego postępu w onkologii molekularnej i wirusologii, wiele mechanizmów ciągle pozostaje niewyjaśnionych. Poznawanie roli wirusów w procesie kancerogenezy może przyczynić się odkrywania nowych leków i opracowywania ulepszonych terapii przeciwnowotworowych. Poza przedstawionymi w niniejszym artykule nowotworami należy dodać, iż EBV jest powiązany również z nowotworami piersi, mięsakami gładkokomórkowymi, chłoniakami angioimmunoblastycznymi z komórek T i chłoniakami z komórek T/NK.

\section{PIŚMIENNICTWO}

1. Hassanpour SH, Dehghani M (2017) Review of cancer from perspective of molecular. J Canc Res Pract 4(4): 127-129

2. Chang Y, Moore PS, Weiss RA (2017) Human oncogenic viruses: nature and discovery.

3. Tashiro H, Brenner MK (2017) Immunotherapy against cancer-related viruses. Cell Res 27(1): 59-73

4. Kliszczewska E, Jarzyński A, Boguszewska A, Pasternak J, Polz-Dacewicz M (2017) Epstein-Barr virus-pathogenesis, latency and cancers. J Pre Clin Clin Res 11: 142-146

5. Żuk-Wasek A (2012) Charakterystyka białek wirusa Epsteina-Barr-ich udział w zakażeniu latentnym i powiązanie z procesami nowotworzenia. Post Mikrobiol 51(3): 191-201

6. Chawla JPS, Iyer N, Soodan KS i wsp. (2015) Role of miRNA in cancer diagnosis, prognosis, therapy and regulation of its expression by Epstein-Barr virus and human papillomaviruses: with special reference to oral cancer. Oral Oncol 51(8): 731-737

7. Polz-Gruszka D, Morshed K, Stec A, Polz-Dacewicz M (2015) Prevalence of Human papillomavirus (HPV) and Epstein-Barr virus (EBV) in oral and oropharyngeal squamous cell carcinoma in south-eastern Poland. Infect Agent Cancer 10(1): 1-7

8. Shannon-Lowe C, Rickinson A (2019) The Global Landscape of EBV-Associated Tumours. Front Oncol 9: 713

9. Fugl A, Andersen CL (2019) Epstein-Barr virus and its association with disease-a review of relevance to general practice. BMC Fam Pract 20(1): 1-8

10. Kang MS, Kieff E (2015) Epstein-Barr virus latent genes. Experimental \& molecular medicine 47(1): 1-16

11. Smatti MK, Al-Sadeq DW, Ali NH, Pintus G, Abou-Saleh H, Nasrallah GK (2018) Epstein-Barr virus epidemiology, serology, and genetic variability of LMP-1 oncogene among healthy population: an update. Front Oncol 8: 211

12. Nonoyama M, Kawai Y, Pagano, JS (1975) Detection of Epstein-Barr virus DNA in human tumors. Bibl. Haematol. (40): 577-583

13. Stanfield BA; Luftig MA (2017) Recent advances in understanding Epstein-Barr virus. F1000Res 6: 386

14. Jha HC, Pei Y, Robertson ES (2016) Epstein-Barr virus: diseases linked to infection and transformation. Front Microbiol 7: 1602

15. Li H, Liu S, Hu J, Luo X, Li N, Bode AM, Cao Y (2016) Epstein-Barr virus lytic reactivation regulation and its pathogenic role in carcinogenesis Int J Biol Sci 12(11): 1309

16. Fernandes Q, Merhi M, Raza A, Inchakalody VP, Abdelouahab N, Zar Gul AR, Dermime S i wsp. (2018) Role of epstein-barr virus in the pathogenesis of head and neck cancers and its potential as an immunotherapeutic target. Front Oncol 8: 257

17. El-Sharkawy A, Al Zaidan L, Malki A (2018) Epstein-Barr virus-associated malignancies: Roles of viral oncoproteins in carcinogenesis Front Oncol 8: 265

18. Bocian J, Januszkiewicz-Lewandowska D (2011) Zakażenia EBV-cykl życiowy, metody diagnostyki, chorobotwórczość. Postepy Hig Med Dosw 65

19. Ali AS, Al-Shraim M, Al-Hakami AM, Jones IM (2015) Epstein-Barr virus: clinical and epidemiological revisits and genetic basis of oncogenesis. Open Virol J 9: 7

20. Tsao SW, Tsang CM, To KF, Lo KW (2015) The role of Epstein-Barr virus in epithelial malignancies. The Journal of pathology 235(2): 323 333

21. Kanda T, Yajima M, Ikuta K (2019) Epstein-Barr virus strain variation and cancer. Cancer Sci 110(4): 1132-1139

22. Ribeiro J, Oliveira A, Malta M, Oliveira C, Silva F, Galaghar A i wsp. (2017) Clinical and pathological characterization of Epstein-Barr virus-associated gastric carcinomas in Portugal. World J Gastroenterol 23(40): 7292 
23. Nishikawa J, Iizasa H, Yoshiyama H, Shimokuri K, Kobayashi Y, Sasaki S i wsp. (2018) Clinical importance of Epstein-Barr virus-associated gastric cancer. Cancers 10(6): 167

24.Shinozaki-Ushiku A, Kunita A, Fukayama M. (2015) Update on Epstein-Barr virus and gastric cancer. Int J Oncol 46(4): 1421-1434

25. Naseem M, Barzi A, Brezden-Masley C, Puccini A, Berger MD, Tokunaga R i wsp. (2018) Outlooks on Epstein-Barr virus associated gastric cancer. Cancer Treat Rev 66: 15-22

26. Singh S, Jha HC (2017) Status of Epstein-Barr virus coinfection with Helicobacter pylori in gastric cancer. J Oncol 2017

27. Zhang J, Huang T, Zhou Y, Cheng AS, Yu, J, To KF, Kang W (2018) The oncogenic role of Epstein-Barr virus-encoded micro RNA s in Epstein-Barr virus-associated gastric carcinoma. J Cell Mol Med 22(1): 38-45

28. Tavakoli A, Monavari SH, Solaymani Mohammadi F, Kiani SJ, Armat S, Farahmand M (2020) Association between Epstein-Barr virus infection and gastric cancer: a systematic review and meta-analysis. BMC Cancer 20: 1-14

29. Al-Thawadi H, Gupta I, Jabeen A, Skenderi F, Aboulkassim T, Yasmeen A i wsp. (2020) Co-presence of human papillomaviruses and Epstein-Barr virus is linked with advanced tumor stage: a tissue microarray study in head and neck cancer patients. Cancer Cell Int 20(1): $1-13$
30. Gołąbek K, Gaździcka J, Ostrowska Z. (2018) Wybrane uwarunkowania genetyczne zapadalności na raka płaskonabłonkowego głowy i szyi z uwzględnieniem niektórych genów kontroli cyklu komórkowego i naprawy DNA. Postepy Hig Med Dosw 72

31. Tsao SW, Tsang CM, Lo KW (2017) Epstein-Barr virus infection and nasopharyngeal carcinoma. Philos Trans R Soc Lond B Biol Sci 372(1732): 20160270

32. Vranic S, Cyprian FS, Akhtar S, Al Moustafa AE (2018) The role of epstein-barr virus in cervical cancer: a brief update. Front Oncol 8: 113

33. Hau PM, Lung HL, Wu M, Tsang CM, Wong KL, Mak NK, Lo KW (2020) Targeting Epstein-Barr Virus in Nasopharyngeal Carcinoma. Front Oncol 10

34. Jha HC, Banerjee S, Robertson ES (2016) The role of gammaherpesviruses in cancer pathogenesis. Pathogens 5(1): 18

35. Petrara MR, Giunco S, Serraino D, Dolcetti R, De Rossi A (2015) Post-transplant lymphoproliferative disorders: from epidemiology to pathogenesis-driven treatment. Cancer Lett 369(1): 37-44

36. Crombie JL, LaCasce AS (2019) Epstein Barr virus associated B-cell lymphomas and iatrogenic lymphoproliferative disorders. Front Oncol 9: 109

\section{Epstein-Barr virus in selected cancer diseases}

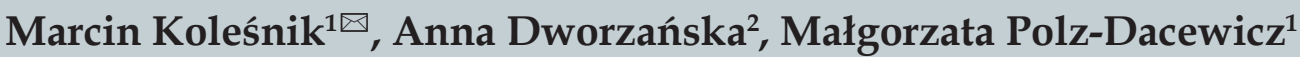

${ }^{1}$ Department of Virology with SARS Laboratory, Medical University of Lublin

${ }^{2}$ Specialist Hospital in Radom

$\llbracket$ Corresponding author: marcinkolesnik@umlub.pl

Keywords: Epstein-Barr virus, cancer diseases, viral infection

\section{SUMMARY}

Viral infections contribute to many cancers worldwide and represent a significant percentage of deaths. Oncogenic viruses include the Epstein-Barr virus, which is the main cause of infectious mononucleosis and exhibits tropism towards B lymphocytes. Due to the presence of genes responsible for latency, it can contribute to many pathological conditions. Examples of this are high-fatal malignancies located in the stomach as well as in the head and neck. Moreover, this virus poses a serious threat to immunocompromised people, which is a significant problem nowadays due to the increasing number of patients undergoing immunosuppressive therapy. Particular attention in this case is lymphoproliferative disorders after transplantation, which are a malignant neoplasm associated with EBV infection. This review focuses on the role of the Epstein-Barr virus in selected cancers. 